Fandini, et al/Jurnal Ekonomi Syariah Teori dan Terapan Vol. 6 No. 11 November 2019: 2185-2197; PENGARUH TRUST TERHADAP NIAT ULANG BERWAKAF UANG PADA BADAN WAKAF AL QUR'AN SURABAYA MELALUI BELIEF

\title{
PENGARUH TRUST TERHADAP NIAT ULANG BERWAKAF UANG PADA BADAN WAKAF AL QUR'AN SURABAYA MELALUI BELIEF ${ }^{1}$
}

\author{
Hesti Dwi Fandini \\ Departemen Ekonomi Syariah-Fakultas Ekonomi dan Bisnis-Universitas Airlangga \\ Email: hdfandini@gmail.com \\ Ririn Tri Ratnasari \\ Departemen Ekonomi Syariah-Fakultas Ekonomi dan Bisnis-Universitas Airlangga \\ Email: ri.ratnasari@gmail.com
}

\begin{abstract}
:
This study aims to determine the effect of trust on the repeat intention to give cash wagf at BWA Surabaya through beliefs which include aspects of attitude, subjective norms, and perceived behavioral control. Retrieval of data in this study using a questionnaire with a total sample obtained by 35 waqif, who had already given money endowment at BWA Surabaya in one past year. The sampling technique are both non probability and simple random sampling. This research uses a quantitative approach with path analysis techniques. The endogenous variable in this study is the repeat intention to give cash wagf, while the exogenous variable used is trust and the intervening endogenous variable is beliefs. The results of this study showed that trust has a positive and significant influence on beliefs. Nevertheless, trusts does not affect the repeat intention to give cash waqf. However, trusts indirectly affects to the repeat intention to give cash wagf through beliefs variables that have a positive and significant effect on the repeat intention to give cash wagf at BWA Surabaya. Suggestions for BWA Surabaya should be maintaining and increasing trusts and beliefs of waqif which can increase the repeat intention of waqif to give cash waqf at BWA Surabaya.
\end{abstract}

Keywords: Trust, Wakaf, Belief

\section{PENDAHULUAN}

Kemiskinan masih menjadi masalah serius di Indonesia. Menurut data Badan Pusat Statistik (BPS) jumlah penduduk miskin di Indonesia per September 2018 mencapai 25,67 juta jiwa atau 9,66\% dari jumlah penduduk Indonesia (bps.go.id). Kesenjangan ekonomi masih terjadi antara si miskin dan si kaya. sedangkan Islam mewajibkan sirkulasi kekayaan terjadi pada semua anggota masyarakat dan mencegah terjadinya sirkulasi kekayaan hanya pada segelintir orang (An Nabhani, 2010:338).

Sistem ekonomi Islam memiliki
peluang untuk kembali $\begin{array}{r}\text { tampil } \\ \text { terhadap }\end{array}$
memberikan solusi
permasalahan ekonomi yang ada untuk
menyejahterakan masyarakat (Takhim,
2016:12). Didalam Islam terdapat
beberapa sumber dana sosial untuk
pendistribusian harta kekayaan, yakni
zakat, infak, shodaqoh, dan wakaf
(ZISWAF). Wakaf merupakan salah satu
sumber dana yang memiliki potensi dalam
pengembangan ekonomi umat (Munir,
2013). Kata al wagf dalam Bahasa Arab
artinya menahan harta untuk diwakafkan,
tidak dipindahmilikkan (Depag:2006).

1 Jurnal ini merupakan bagian dari skripsi yang ditulis oleh Hesti Dwi Fandini, NIM:
041311433126 , yang diuji pada 23 September 2019. 
Fandini, et al/Jurnal Ekonomi Syariah Teori dan Terapan Vol. 6 No. 11 November 2019: 2185-2197; PENGARUH TRUST TERHADAP NIAT ULANG BERWAKAF UANG PADA BADAN WAKAF AL QUR'AN SURABAYA MELALUI BELIEF

Saat ini, wacana yang banyak berkembang di masyarakat adalah wakaf vang. Penerapan wakaf uang pada masa sekarang mempunyai keunggulan yang lebih besar daripada wakaf tradisional, yaitu benda bergerak atau tidak bergerak (Al Arif: 2012:298). Pada umumnya, seseorang memahami tentang wakaf vang terkadang hanya didasarkan oleh aspek religiusitasnya sebagai seorang muslim (Rahmawati, 2013:98). Akan tetapi, secara khusus seorang wakif berniat untuk berwakaf karena banyak faktor yang mendorongnya, baik aspek ekonomi, sosial, budaya, dan kepercayaan yang didasari oleh pengetahuan dan pemahamannya mengenai wakaf uang.

$$
\text { Kepercayaan atau trust }
$$

berpengaruh terhadap niat ulang wakif untuk berwakaf. Menurut Cofta (2006, dalam Ekawati, 2017) kepercayaan merupakan sebuah keyakinan seseorang yang digerakkan oleh bukti-bukti dimana kebutuhan orang tersebut dipenuhi oleh orang yang dipercayakan.

Keyakinan (belief) juga merupakan faktor penting didalam mempengaruhi niat seseorang dalam melakukan sesuatu. Didalam Theory of Planned Behavior yang dikemukakan oleh Ajzen (2005) terdapat tiga keyakinan yang mendasari niat berperilaku, yaitu behavioral belief yang meliputi sikap, normative belief yang meliputi norma subjektif, dan control belief yang meliputi kontrol perilaku yang dipersepsikan.
Selain trust dan belief, faktor yang tidak kalah penting dalam penelitian ini adalah niat ulang. Menurut Ajzen dan Fisbein (1991, dalam Alcock dan Sadava, 2014) pada akhirnya masyarakat akan melakukan sesuatu yang telah mereka niati, dan prediktor tunggal terbaik dari perilaku tersebut adalah niat itu sendiri.

Badan Wakaf Al Qur'an Surabaya adalah cabang dari Badan Wakaf Al Qur'an yang berpusat di Jakarta. BWA Surabaya bertugas menghimpun dana wakaf uang dari masyarakat muslim di masing-masing daerah. BWA telah berhasil menggait hati masyarakat sehingga bersedia memberikan sebagian hartanya untuk diwakafkan. Terbukti hingga Agustus 2019, tercatat lebih dari 450 ribu wakif telah bergabung dalam BWA (wakafquran.org).

Dengan demikian, penelitian ini bertujuan untuk melihat bagaimana trust BWA Surabaya menurut para wakif yang pernah berwakaf vang, bagaimana belief wakif terhadap BWA Surabaya, serta sejauh mana hal tersebut berpengaruh terhadap niat ulang wakif untuk kembali berwakaf uang pada BWA Surabaya.

\section{LANDASAN TEORI DAN PENGEMBANGAN HIPOTESIS}

\section{Wakaf Uang}

Wakaf vang adalah wakaf yang dilakukan seseorang, kelompok orang, lembaga atau badan hukum dalam bentuk uang tunai (Mardani, 2015). Menurut Departemen Agama, wakaf vang didefinisikan sebagai wakaf yang 
Fandini, et al/Jurnal Ekonomi Syariah Teori dan Terapan Vol. 6 No. 11 November 2019: 2185-2197; PENGARUH TRUST TERHADAP NIAT ULANG BERWAKAF UANG PADA BADAN WAKAF AL QUR'AN SURABAYA MELALUI BELIEF

dilakukan seseorang, sekelompok orang, dan lembaga atau badan hukum dalam bentuk uang (Depag: 2006). Wakaf uang dianggap lebih bernilai produktif dan strategis dibanding wakaf-wakaf lainnya. Hal ini disebabkan vang sebagai alat beli/alat tukar dan modal lebih dibutuhkan masyarakat daripada barangbarang yang tidak bergerak seperti tanah (Karim dan Sahroni, 2015).

\section{Trust}

Kepercayaan adalah keyakinan atau persepsi seseorang bahwa pihak tertentu (orang atau lembaga) akan bertindak baik demi terpenuhinya tujuan atau harapan (Nuraini, dkk., 2018). Menurut Moorman 1993, dalam Dharmmestha, 2005) kepercayaan didefinisikan kesediaan (willingness) individu untuk menggantungkan dirinya pada pihak lain yang terlibat dalam pertukaran karena individu mempunyai keyakinan (confidence) kepada pihak lain.

\section{Pengukuran Trust}

Morgan dan Hunt (1994), dalam Wibawa dan Ratnasari (2017) menyebutkan terdapat enam indikator trust (kepercayaan), antara lain:

1. Pemberian pelayanan yang konsisten

2. Penawaran produk-produk yang berkualitas

3. Terbuka dalam penyampaian informasi tentang produk-produk yang ditawarkan

4. Ketepatan waktu dalam pelayanan produk
5. Pemberian respon yang baik

6. Pemberian kesan yang baik

Belief

Keyakinan (belief) juga merupakan faktor penting didalam mempengaruhi niat seseorang dalam melakukan sesuatu. Didalam Theory of Planned Behavior yang dikemukakan oleh Ajzen (2005) terdapat tiga keyakinan yang mendasari niat berperilaku, yaitu behavioral belief (keyakinan berperilaku) yang meliputi sikap, normative belief (keyakinan normatif) yang meliputi norma subjektif, dan control belief (keyakinan kontrol) yang meliputi kontrol perilaku yang dipersepsikan. Semua keyakinan tersebut mengasosiasikan perilaku menarik dengan atribut dari beberapa jenis, baik itu suatu hasil, harapan normatif, atau sumber daya yang dibutuhkan untuk melakukan perilaku.

\section{Pengukuran Belief}

Hasbullah, akk menyebutkan untuk mengukur variabel belief harus melalui tiga aspek, yaitu sikap, norma subjektif, dan kontrol perilaku yang dipersepsikan, indikatornya adalah sebagai berikut:

a. Sikap

1. Meyakini bahwa wakaf uang bermanfaat bagi masyarakat luas,

2. Meyakini bahwa wakaf uang berpahala,

3. Mempunyai persepsi yang positif terhadap wakaf uang,

4. Meyakini bahwa wakaf uang adalah ide yang bagus untuk berderma. 
Fandini, et al/Jurnal Ekonomi Syariah Teori dan Terapan Vol. 6 No. 11 November 2019: 2185-2197; PENGARUH TRUST TERHADAP NIAT ULANG BERWAKAF UANG PADA BADAN WAKAF AL QUR'AN SURABAYA MELALUI BELIEF

b. Norma Subjektif

1. Mayoritas orang-orang yang penting bagi responden mendukung ia untuk berwakaf vang,

2. Rekan-rekan responden mendukung ia untuk berwakaf vang,

3. Responden merasakan adanya ekspektasi agar ia berwakaf vang dari mayoritas orangorang yang penting bagi dirinya

c. Kontrol Perilaku yang Dipersepsikan

1. Responden mempunyai sumber daya keuangan yang dipunya cukup untuk berwakaf uang,

2. Responden mampu untuk menemui pengelola wakaf,

3. Responden memiliki pengetahuan yang cukup untuk berwakaf uang,

4. Responden mampu mengurus penyerahan wakaf vang dengan segala mekanismenya.

Niat Ulang

Niat ulang didefinisikan sebagai tindakan pasca pembelian yang disebabkan oleh adanya kepuasan yang dirasakan konsumen atas produk yang telah dibeli atau dikonsumsi sebelumnya (Aini dan Ratnasari, 2014). Apabila produk tersebut telah memenuhi harapan konsumen, maka ia akan membeli kembali produk tersebut, dan sebaliknya (Schifman dan Kanuk, 2004:73).
Menurut para ahli figh, niat mempunyai makna tamyi>z (pembeda), diantaranya ada dua macam, yaitu:

1. Pembeda antara ibadah yang satu dengan yang lain. Contohnya adalah antara shalat fardhu (wajib) dengan shalat sunnah.

2. Pembeda antara kebiasaan dengan ibadah. Contohnya menahan diri dari makan karena puasa dengan menahan diri dari makan demi kesembuhan.

Niat berperilaku juga ada didalam proses pengambilan keputusan pembelian menurut perspektif Islam. Menurut Ratnasari (2012) proses pengambilan keputusan konsumen muslim diawali dengan mengenali masalah, lalu melakukan pencarian informasi dan evaluasi alternatif. Didalam evaluasi alternatif, terdapat konsep maslahah yaitu mengedepankan manfaat dengan persepsi menolak kemudharatan, persepsi memenuhi kebutuhan secara Islami yaitu tidak boros dan menjauhi yang haram, dan persepsi mardhatillah yaitu mengutamakan ridho Allah dalam segala aktifitas manusia.

\section{Pengukuran Niat Ulang}

Menurut Ferdinand (2002:129, dalam Hajar dan Ratnasari, 2018) salah satu dimensi dari perilaku pembelian adalah niat membeli ulang. Berdasarkan teori-teori niat beli ulang yang ada, ia menyimpulkan bahwa niat beli 
Fandini, et al/Jurnal Ekonomi Syariah Teori dan Terapan Vol. 6 No. 11 November 2019: 2185-2197; PENGARUH TRUST TERHADAP NIAT ULANG BERWAKAF UANG PADA BADAN WAKAF AL QUR'AN SURABAYA MELALUI BELIEF

ulang dapat diukur melalui indikator-indikator sebagai berikut:

1. Niat transaksional

2. Niat referensial:

3. Niat Preferensial

4. Niat Eksploratif

Adapun penelitian yang dilakukan oleh Johari, dkk. (2015) untuk mengukur variabel niat ulang berwakaf uang sebagai berikut:

1. Responden akan kembali berwakaf vang dalam waktu dekat,

2. Ada peluang yang besar bagi responden untuk kembali berwakaf vang di masa depan,

3. Responden akan kembali berniat berwakaf uang dalam waktu tiga bulan mendatang,

4. Responden tidak mempunyai niat untuk kembali berwakaf uang pada lembaga wakaf.

Hipotesis

Menurut Adji dan Semuel (2013) trust adalah kepercayaan pihak tertentu terhadap yang lain dalam melakukan hubungan transaksi berdasarkan suatu keyakinan (belief) bahwa orang yang dipercayainya tersebut akan memenuhi segala kewajibannya secara baik, sesuai yang diharapkan.

Menurut Dabholkar (1995, dalam Wibawa dan Ratnasari, 2017), kepercayaan konsumen tergantung dari pengalaman konsumen dalam mengkonsumsi barang atau jasa dan menerima informasi yang baik dari penyedia jasa. Informasi yang baik itu juga akan menambah pengetahuan konsumen dan juga akan mempengaruhi keyakinan konsumen terhadap sesuatu. Didalam penyampaian informasi Islam mengajarkan untuk melandasinya dengan kejujuran.

Menurut Engel et al (1998, dalam Gayatri, 2013) sifat yang penting dari sikap adalah kepercayaan dalam memegang sikap tersebut. Beberapa sikap mungkin dipegang dengan keyakinan yang kuat, sementara yang lain mungkin ada dengan tingkat kepercayaan yang minimum. Kepercayaan dihubungkan dengan sikap penting karena dua alasan. Pertama, hal ini dapat mempengaruhi kekuatan hubungan di antara sikap dan perilaku. Sikap yang dipegang dengan penuh kepercayaan biasanya akan jauh lebih diandalkan untuk membimbing perilaku. Kedua, kepercayaan dapat mempengaruhi kerentanan sikap terhadap perubahan. Sikap menjadi lebih resistan terhadap perubahan bila dipegang dengan kepercayaan yang lebih besar.

Ajzen mengembangkan Theory of Reasoned Action dengan menambahkan kepercayaan individu dan persepsi individu mengenai kontrol perilaku, yaitu kepercayaan bahwa individu dapat melakukan suatu perilaku didasari oleh kemampuan untuk melakukannya. Hasil penelitian yang dilakukan oleh Wulandari (2017) menunjukkan bahwa kepercayaan memiliki pengaruh yang signifikan dalam 
Fandini, et al/Jurnal Ekonomi Syariah Teori dan Terapan Vol. 6 No. 11 November 2019: 2185-2197; PENGARUH TRUST TERHADAP NIAT ULANG BERWAKAF UANG PADA BADAN WAKAF AL QUR'AN SURABAYA MELALUI BELIEF

menentukan perilaku nasabah melalui intensi untuk melakukan wakaf uang di lembaga wakaf.

H1: Terdapat hubungan positif antara variabel Trust dengan belief pada

Badan Wakaf Al Qur'an Surabaya.

$$
\text { Menurut Swidi (2012) sikap }
$$

konsumen berdasarkan teori perilaku yang direncanakan, perasaan menguntungkan atau tidak menguntungkan mendasari seseorang melakukan sesuatu. Menurut Suprapti (2010:135) sikap merupakan suatu ekspresi perasaan seseorang yang merefleksikan kesukaan atau ketidaksukaanya terhadap sesuatu objek. Karena sikap seseorang merupakan hasil dari suatu proses psikologi, maka hal itu tidak dapat diamati secara langsung tetapi harus disimpulkan dari apa yang dikatakan atau dilakukannya.

\section{Adapun menurut Al Ghazali,} bahwa salah satu pendorong yang membangkitkan niat ialah semata-mata karena Allah. Yang dimaksud dengan karena Allah dapat berarti (1) karena takut kepada Allah, (2) karena mengharap ridho Allah atau (3) karena cinta kepada Allah (Mujiburrahman, 2011). Hal ini menunjukkan bahwa dalam perspektif Islam, sikap dapat mempengaruhi niat karena seseorang dapat meninggalkan atau melakukan suatu perilaku tergantung ia memandang perilaku tersebut membawa ridho Allah SWT atau murka-Nya.
Norma sosial, tokoh masyarakat, anggota keluarga, dan teman memiliki peran penting dalam mempengaruhi niat seseorang (Shanmugham dan Ramya, 2012). Hal ini dikuatkan oleh pernyataan McKnight yaitu bahwa pada umumnya norma subjektif didasari oleh keinginan seseorang untuk berperilaku sesuai dengan ekspektasi teman-teman, keluarga, atau kelompok sosial (Cazacu, Rotsios dan Moshonas, 2014).

Menurut Lee (2009, dalam Dewi dan Ardani, 2016) menyatakan bahwa pengaruh norma subjektif, menjadi prediktor utama dalam pengambilan niat pembelian dimana pengaruh norma subjektif mampu untuk menyarankan, mengolah dan memperkuat suatu tindakan atau perilaku pembelian konsumen.

H2: Terdapat hubungan antara variabel Belief dengan niat ulang berwakaf vang pada Badan Wakaf Al Qur'an Surabaya

Hubungan kepercayaan terhadap niat beli ulang diperkuat dengan teori dimana kepercayaan sering dianggap sangat penting untuk hubungan jangka panjang dan mempengaruhi niat pada nasabah. Hal tersebut didukung oleh penelitian Erikkson Vaghult (2000) dan Sirdesmukh et al (2002), keduanya menjelaskan bahwa kepercayaan secara langsung mempengaruhi niat beli ulang.

Menurut Dabholkar (1995, dalam Viandhy dan Ratanasari, 2014) menyatakan bahwa kepercayaan 
Fandini, et al/Jurnal Ekonomi Syariah Teori dan Terapan Vol. 6 No. 11 November 2019: 2185-2197; PENGARUH TRUST TERHADAP NIAT ULANG BERWAKAF UANG PADA BADAN WAKAF AL QUR'AN SURABAYA MELALUI BELIEF

konsumen dapat dijelaskan melalui 3 (tiga) dimensi, yaitu pengalaman masa lalu, informasi dan atusiasme. Dabholkar (1995) juga menyebutkan, kepercayaan konsumen tergantung dari pengalaman konsumen dalam mengkonsumsi barang atau jasa dan menerima informasi yang baik dari penyedia jasa. Apabila pengalaman konsumen tersebut baik terhadap produsen atau penyedia jasa, maka tidak jarang konsumen akan melakukan tindakan ulang terhadap hal tersebut. (Viandhy dan Ratnasari, 2014)

H3: Terdapat hubungan antara variabel Trust dengan niat ulang berwakaf vang pada Badan Wakaf Al Qur'an Surabaya

\section{METODE PENELITIAN}

Pendekatan yang akan digunakan dalam penelitian ini adalah pendekatan kuantitatif. Pendekatan kuantitatif digunakan untuk menjawab rumusan masalah. Pendekatan kuantitatif adalah pendekatan ilmiah terhadap pengambilan keputusan manajerial dan ekonomi (Kuncoro, 2011:3). Tujuan penelitian kuantitatif adalah untuk menguji atau memverifikasi teori, meletakkan teori secara deduktif untuk selanjutnya menjadi landasan dalam hal penemuan dan pemecahan masalah.

\section{Definisi Operasional}

1. Trust dalam penelitian ini adalah sikap percaya dan yakin yang dimiliki oleh wakif terhadap Badan Wakaf Al Qur'an Surabaya yang memiliki integritas dalam memberikan pelayanan yang terbaik kepada wakif.

2. Belief pada penelitian ini adalah meliputi behavioral belief yakni sikap wakif tentang berwakaf uang pada Badan Wakaf Al Qur'an Surabaya untuk menerima atau menolaknya. Kemudian, normative belief yakni tekanan sosial yang diterima wakif untuk melakukan atau tidak melakukan wakaf uang pada BWA Surabaya. Selanjutnya, control belief adalah kontrol perilaku yang dipersepsikan wakif mengenai kemudahan atau kesulitan untuk berwakaf uang pada Badan Wakaf Al Qur'an Surabaya.

3. Niat Ulang Berwakaf Uang pada Badan Wakaf Al Qur'an Surabaya pada Badan Wakaf Al Qur'an Surabaya dalam penelitian ini adalah niat wakif untuk kembali berwakaf uang pada Badan Wakaf Al Qur'an Surabaya sesuai dengan prinsip syariah. Indikator variabel ini mengacu pada teori dan pernyataan-pernyataan dari berbagai sumber yang ada.

\section{Teknik Analisis}

Teknik analisis yang digunakan dalam penelitian ini adalah analisis jalur (path analysis). Analisis jalur merupakan alat analisis statistik untuk menguji eksistensi variabel intervensi terhadap hubungan antara variabel $X$ terhadap variabel $Y$.

Persamaan struktural untuk variabel endogen intervening (Z) adalah (Solimun, 2002:97): 
Fandini, et al/Jurnal Ekonomi Syariah Teori dan Terapan Vol. 6 No. 11 November 2019: 2185-2197; PENGARUH TRUST TERHADAP NIAT ULANG BERWAKAF UANG PADA BADAN WAKAF AL QUR'AN SURABAYA MELALUI BELIEF

$$
Z=X+e
$$

Keterangan :

$\mathrm{Z}=$ Belief

= Koefisien path dari variabel eksogen

ke variabel endogen

$\mathrm{x}=$ Trust

e $=$ Standard error

Penelitian ini juga menggunakan persamaan struktural untuk variabel endogen $(Y)$ adalah :

$$
Y=Z+Y X+e
$$

Keterangan:

$Y=$ Niat Ulang Berwakaf Uang pada Badan

Wakaf Al Qur'an Surabaya.

$Y=$ Koefisien path dari variabel endogen

ke variabel eksogen

$\mathrm{Z}=$ Belief

$\mathrm{X}=$ Trust

$\mathrm{e}=$ Standard error

$$
Y=\beta Z+\gamma X+e
$$

Keterangan:

$Y=$ Niat Ulang Berwakaf Uang pada Badan

Wakaf Al Qur'an Surabaya.

$\beta=$ Koefisien path dari variabel

endogen ke variabel eksogen

$Y=$ Koefisien path dari variabel endogen

ke variabel eksogen

$\mathrm{Z}=$ Belief

$\mathrm{X}=$ Trust

e $=$ Standard error

\section{HASIL PENELITIAN DAN \\ PEMBAHASAN}

Uji Outlier

Uji outlier ialah uji yang digunakan secara bersamaan untuk mengamati distribusi normal data. Ini berarti jika data tidak berdistribusi normal, maka dilakukan eliminasi data yang outlier atau ekstrim, sebaliknya jika data sudah berdistribusi normal maka tidak diperlukan lagi eliminasi data. Uji outlier terdiri dari outlier univariate dan multivariate. Outlier univariate dilakukan dengan mengamati nilai Z score. Data dikatakan tidak terjadi outlier jika mempunyai nilai minimum dan maksimum $Z$ score kurang dari +3 (Ferdinand, 2002). Pengujian outlier secara univariate ini dilakukan dengan menggunakan software SPSS.

Hasilnya menunjukkan bahwa pada pengujian outlier univariate dengan sampel 35 responden menunjukkan nilai z score minimum dan maksimum seluruhnya memenuhi standar maksimum +3 atau -3 . Sehingga data tidak ada yang dioutlier dan seluruh data dapat diproses ke tahap selanjutnya. Setelah dilakukan uji outlier univariate maka tahap selanjutnya dilakukan uji outlier multivariate. Pengujian outlier secara multivariate dilakukan dengan menggunakan nilai Mahalanobis dengan menggunakan software AMOS. Standar multivariate outlier dari Mahalanobis adalah menggunakan nilai Chi Square tabel. Berdasarkan tabel nilai Chi Square pada 0,001 dan pada jumlah variabel 3 adalah 16,42.

\section{Uji Normalitas}

Normalitas terjadi apabila skor pada tiap variabel mengikuti distribusi normal. Pengujian ini dilakukan dengan pengamatan nilai $C R$ skewness (kemiringan) dan $C R$ kurtosis (keruncingan). Data dikatakan 
Fandini, et al/Jurnal Ekonomi Syariah Teori dan Terapan Vol. 6 No. 11 November 2019: 2185-2197; PENGARUH TRUST TERHADAP NIAT ULANG BERWAKAF UANG PADA BADAN WAKAF AL QUR'AN SURABAYA MELALUI BELIEF

berdistribusi normal jika mempunyai nilai CR skewness dan kurtosis sebesar $\pm 2,58$ dengan tingkat signifikansi sebesar $5 \%$. Penelitian ini menunjukkan data nilai $C R$ skewness dan CR kurtosis dari variabel tingkat marjin murabahah (TMM), FDR dan NPF sebesar masing-masing berada dalam batas antara $-2,58$ sampai 2,58.

\section{Pengujian Hipotesis}

Selanjutnya dilakukan pengujian hipotesis pada data observasi dengan menggunakan software AMOS dan diinterprestasikan melalui tabel berikut ini:

\begin{tabular}{|l|c|c|r|r|r|r|r|r}
\hline & & & $\begin{array}{c}\text { Standardized } \\
\text { Estimate }\end{array}$ & Estimate & S.E. & C.R. & P & Label \\
\hline Belief & $<---$ & Trust & .483 & .536 & .167 & 3.215 & .001 & par_1 \\
\hline Niat.Ulang & $<---$ & Belief & .684 & .687 & .135 & 5.095 & $* * *$ & par_2 \\
\hline Niat.Ulang & $<---$ & Trust & .085 & .094 & .150 & .631 & .528 & par_3 \\
\hline
\end{tabular}

Berdasarkan Tabel tersebut, maka diketahui bahwa:

1. Jika variabel trust berubah maka akan menyebabkan perubahan belief. Tanda positif menunjukkan perubahan yang searah yaitu jika variabel trust meningkat maka belief akan meningkat, dan sebaliknya apabila variabel trust menurun maka belief juga akan menurun dengan nilai koefisien jalur 0,483.

2 Jika variabel belief berubah maka akan menyebabkan perubahan niat ulang wakif untuk berwakaf uang. Tanda positif menunjukkan perubahan yang searah yaitu jika variabel belief meningkat maka niat ulang berwakaf vang akan meningkat, dan sebaliknya apabila variabel belief menurun maka niat ulang berwakaf vang juga akan menurun dengan nilai koefisien jalur 0,684.

3. Jika variabel trust berubah maka akan menyebabkan perubahan niat ulang berwakaf vang. Tanda positif menunjukkan perubahan yang searah yaitu jika variabel trust meningkat maka niat beli ulang akan meningkat, dan sebaliknya apabila variabel trust menurun maka niat ulang berwakaf vang juga akan menurun dengan nilai koefisien jalur 0,085.

\section{Pembahasan}

\section{Pengaruh Trust terhadap Belief Berwakaf Uang pada BWA Surabaya}

Trust memiliki pengaruh signifikan terhadap belief yang meliputi aspek sikap, norma subjektif dan kontrol perilaku yang dipersepsikan dengan nilai CR 3,215. Tingkat signifikansi yang diperoleh adalah 0,001 . Nilai ini lebih kecil dari 0,05, sehingga ini menunjukkan bahwa hipotesis pertama dapat diterima.

Hasil ini sesuai dengan teori yang dikemukakan oleh Adji dan Samuel (2013) bahwa trust adalah kepercayaan pihak tertentu terhadap orang lain dalam melakukan hubungan transaksi berdasarkan keyakinan bahwa orang yang dipercayai akan memenuhi semua kewajibannya dengan baik, seperti yang diharapkan. Dari jawaban responden, banyak yang menganggap bahwa BWA Surabaya telah memberikan layanan secara konsisten dalam mengumpulkan dan mengelola wakaf uang.

Kemudian diperkuat oleh hasil 
Fandini, et al/Jurnal Ekonomi Syariah Teori dan Terapan Vol. 6 No. 11 November 2019: 2185-2197; PENGARUH TRUST TERHADAP NIAT ULANG BERWAKAF UANG PADA BADAN WAKAF AL QUR'AN SURABAYA MELALUI BELIEF

penelitian yang dipaparkan oleh Dabholkar (1995, dalam Wibawa dan Ratnasari, 2017), kepercayaan konsumen tergantung pada pengalaman konsumen dalam mengkonsumsi barang atau jasa dan menerima informasi yang baik dari penyedia layanan. Informasi yang baik juga akan meningkatkan pengetahuan konsumen dan juga akan mempengaruhi kepercayaan konsumen pada sesuatu.

\section{Pengaruh Belief terhadap Niat Ulang}

\section{Berwakaf Uang pada BWA Surabaya}

Hasil penelitian menunjukkan bahwa belief yang memiliki aspek sikap, norma subjektif, dan kontrol perilaku yang dipersepsikan berpengaruh signifikan terhadap niat ulang berwakaf uang dengan nilai CR 5.095. Tingkat signifikansi yang diperoleh adalah 0,000 , nilai ini lebih kecil dari 0,05 . Karena tingkat signifikansi ini kurang dari 0,05, maka belief memengaruhi niat ulang untuk berwakaf vang. Hasil ini konsisten dengan hasil penelitian Peyrot dan Van Doren (1994) yang menyatakan bahwa ada hubungan positif antara keyakinan pada niat ulang berwakaf uang yang mencakup aspek sikap. Kemudian diperkuat oleh penelitian yang dilakukan oleh Wijaya (2014) yang menunjukkan bahwa sikap positif terhadap sesuatu dapat meningkatkan niat pembelian kembali konsumen atau produk. Niat pembelian kembali pada dasarnya adalah perilaku pelanggan di mana pelanggan memberikan respons positif terhadap kualitas produk / layanan perusahaan dan bermaksud untuk mengkonsumsi produk perusahaan lagi (Cronin, et al. 1992).

Penelitian ini menunjukkan bahwa belief wakif yang memiliki aspek sikap, norma subjektif dan kontrol perilaku yang dipersepsikan muncul sebagai tanggapan dari waqif dalam program BWA Surabaya. Pengaruh belief wakif yang mencakup sikap tercermin dalam jawaban responden pada indikator kedua dan ketiga, yaitu wakif meyakini bahwa berwakaf uang di BWA Surabaya adalah berpahala dan wakif memiliki persepsi positif dalam berwakaf uang di BWA Surabaya. Kemudian, pengaruh belief yang meliputi norma subjektif dapat dilihat dari jawaban responden pada indikator keenam, bahwa rekan-rekan wakif mendukungnya untuk berwakaf vang di BWA Surabaya, ini berarti bahwa BWA Surabaya sudah cukup terkenal di lingkungan wakif. Ini juga menunjukkan bahwa orang-orang di sekitar wakif termasuk orang-orang sholih yang selalu mendukung untuk berbuat kebaikan.

\section{Pengaruh Trust terhadap Niat Ulang}

\section{Berwakaf Uang pada BWA Surabaya}

Trust secara tidak signifikan berpengaruh terhadap niat ulang berwakaf vang pada BWA Surabaya. Tingkat signifikansi yang diperoleh oleh nilai 0,528, nilai ini melebihi 0,5. Maka pengaruh trust terhadap niat ulang berwakaf uang tidak signifikan.

Hasil ini juga terjadi pada penelitian sebelumnya yang dilakukan oleh Fuadah Johari, dkk. (2015) dalam 
Fandini, et al/Jurnal Ekonomi Syariah Teori dan Terapan Vol. 6 No. 11 November 2019: 2185-2197; PENGARUH TRUST TERHADAP NIAT ULANG BERWAKAF UANG PADA BADAN WAKAF AL QUR'AN SURABAYA MELALUI BELIEF

studinya yang berjudul "Faktor-Faktor yang Mempengaruhi Mengulangi Kontribusi Wakaf Tunai pada Filantropi Islam". Hasil penelitiannya menunjukkan bahwa trust tidak berpengaruh terhadap niat ulang wakif berwakaf pada lembaga filantropi Islam. Kemudian, penelitian Wardoyo dan Intan (2017) yang menunjukkan hasil bahwa trust (kepercayaan) tidak berpengaruh terhadap keputusan pembelian pada mahasiswa Universitas Gunadarma.

Temuan ini tidak sejalan dengan teori bahwa kepercayaan sering dianggap sangat penting untuk hubungan jangka panjang dan mempengaruhi niat pelanggan. Ini didukung oleh penelitian oleh Erikkson Vaghult (2000) dan Sirdesmukh et al (2002), keduanya menjelaskan bahwa kepercayaan secara langsung mempengaruhi niat pembelian kembali. Kepercayaan atau trust dianggap sebagai dasar dari niat publik untuk menyalurkan dana ke badan amal, salah satunya adalah wakaf. trust pada lembaga pengumpulan wakaf memiliki pengaruh besar untuk mendorong niat dan perilaku konsumen untuk melakukan transaksi uang wakaf ke lembagalembaga ini untuk dikelola secara efektif dan efisien dalam mencapai manfaat untuk masyarakat (Wulandari, 2017). Ini bisa menjadi masukan bagi BWA Surabaya untuk mengembangkan strategi meningkatkan kepercayaan wakif kepadanya.

\section{SIMPULAN}

1. Trust berpengaruh secara signifikan terhadap belief wakif berwakaf uang pada BWA Surabaya. Dengan demikian, sebuah lembaga yang memiliki trust yang baik di benak wakif dapat membentuk belief wakif terhadap lembaga tersebut.

2 Belief wakif berpengaruh secara signifikan terhadap niat ulang berwakaf uang pada BWA Surabaya. Dengan demikian, sebuah lembaga yang memiliki belief wakif yang baik di benak wakif dapat meningkatkan niat ulang wakif berwakaf uang pada Lembaga tersebut.

3. Trust tidak berpengaruh secara signifikan terhadap niat ulang wakif berwakaf uang pada BWA Surabaya. Akan tetapi secara tidak langsung trust berpengaruh terhadap niat ulang berwakaf uang melalui variabel belief. Dengan demikian, BWA Surabaya harus meningkatkan kualitas pelayanannya agar para wakif mempunyai trust untuk kembali berwakaf uang.

\section{DAFTAR PUSTAKA}

Pendekatan Kualitatif dan Kuantitatif. Jurnal Psikologi, Vol. 3 No. 3, hal 194-206.

Ain, Nurul dan Ratnasari. 2015. Pengaruh Citra Merek melalui Sikap Konsumen terhadap Niat Beli Ulang pada Produk Busana Muslim Zoya Di Surabaya. JESTT, Vol. 2 No. 7. 
Fandini, et al/Jurnal Ekonomi Syariah Teori dan Terapan Vol. 6 No. 11 November 2019: 2185-2197; PENGARUH TRUST TERHADAP NIAT ULANG BERWAKAF UANG PADA BADAN WAKAF AL QUR'AN SURABAYA MELALUI BELIEF

Ajzen, Icek. 1991. The Theory of Planned Behavior. Organizational Behavior and Human Decision Processes, Vol. 50, hal. $179-211$.

Alcock, James \& Sadava, Stan. 2014. An Introduction to Social Psychology Global Perspectives. New Delhi: Sage.

Al Farizi, M. 2015. Al-Qawa'id Al-Fiqhiyyah. Al Mabsut Jurnal Studi Islam dan Sosial, Vol. 9, No. 2.

Al Kabisi, M, A. 2004. Hukum Wakaf Kajian Kontemporer Pertama dan Terlengkap tentang Fungsi dan Pengelolaan Wakaf serta Penyelesaian atas Sengketa Wakaf. Jakarta: Dompet Dhuafa dan Republika dan IMaN.

Al Arif, M. Nur Rianto. 2012. Efek Multiplier Wakaf Uang dan Pengaruhnya terhadap Program Pengentasan Kemiskinan. Al Syir'ah-Jurnal IImu Syari'ah dan Hukum, Vol. 46 No. 1, hal 297-314.

An Nabhani, Taqiyuddin. 2010. Sistem Ekonomi Islam. Bogor: Al Azhar Press.

Arifin, MH dan Ratnasari. 2017. Theory of Planned Behavior in Intention to Pay Cash Wagf. Surabaya: Repository Unair.

Badan Wakaf Al Qur'an. 2019. Diakses 20 Agustus 2019 dari Wakaf Qur'an: www.wakafquran.org.

Cazacu, Stela, Rotsios, K. \& Moshonas, G. 2014. Consumers' Purchase Intentions towards Water Buffalo
Milk Products (WBMPs) in the Greater Area of Thessaloniki, Greece. Procedia Economics and Finance, Vol. 9, hal. $407-416$.

Direktorat Pemberdayaan Wakaf. 2006. Fiah Wakaf. Jakarta: Kemenag RI. Ferdinand, A.T. 2000. Structural Equation Modeling dalam Penelitian Manajemen. Semarang: Badan Penerbit Universitas Diponegoro Semarang.

Hasbullah, Nurul Adilah, dkk. 2014. Intention to Contribute in Corporate Waqf: Applying the Theory of Planned Behavior. UMRAN: International Journal of Islamic and Civilizational Studies. Vol. 3, No.1, hal $39-48$.

Johari, Fuadah, dkk. Factors that Influence Repeat Contribution of Cash Waqf in Islamic Philanthropy. Malaysian Accounting Review, Vol. 14 No. 2, hal 56-78.

Mardani, Dr. 2015. Aspek Hukum Lembaga Kevangan Syariah Di Indonesia. Jakarta: Kencana.

Munir, A. 2015. Hadis Tarbawi tentang Teman Bergaul. Jurnal Shaut Al 'Arabiyah, Vol. 3, No. 2 , hal. 16 40.

Noor, Juliansyah. 2015. Metodologi Penelitian: Skripsi, Tesis, Disertasi dan Karya Ilmiah. Jakarta: Kencana.

Nuraini, Ida, dkk. 2018. Faktor-faktor yang Mempengaruhi Intensi dalam Membayar Wakaf Uang pada 
Fandini, et al/Jurnal Ekonomi Syariah Teori dan Terapan Vol. 6 No. 11 November 2019: 2185-2197;

PENGARUH TRUST TERHADAP NIAT ULANG BERWAKAF UANG PADA BADAN WAKAF AL QUR'AN SURABAYA MELALUI BELIEF

Pegawai Kantor Kemenag DKI Jakarta. Maro, Jurnal Ekonomi Syariah dan Bisnis, Vol. 1. No. 2, hal 97-108.

Osman, Amirul. Faiz. 2014. An Analysis of Cash Waqf Participation among Young Intellectuals. 9th International Academic Conference, Istanbul, hal. 711 723.

Ratnasari, Ririn Tri. 2012. Manajemen Pemasaran Islam. Modul 3. Surabaya: Departemen Ekonomi Syariah Fakultas Ekonomi dan Bisnis Universitas Airlangga.

Rozalinda. 2015. Ekonomi Islam: Teori dan Aplikasinya pada Aktivitas Ekonomi. Edisi 1. Jakarta: Rajawali Pers.

Sugiyono. 2010. Metode Penelitian Tindakan Kelas Pendekatan Kuantitatif, Kualitatif, dan $R$ \&D. Bandung: Alfabeta.

Suprapti, Lilik. 2010. Analisis Pengaruh Brand Awarness, Perceived Valve, Organizational Association dan Perceived Quality terhadap Keputusan Pembelian Konsumen. Fakultas Ekonomi Universitas Diponegoro.

Takhim, Muhamad. 2016. Sistem Ekonomi Islam dan Kesejahteraan Masyarakat. Jurnal Al Mabsut, Vol. 10 No. 2.

Viandhy dan Ratnasari. 2014. Pengaruh Kualitas Pelayanan terhadap Niat Ulang dengan Menggunakan
Produk yang Lain melalui Kepercayaan Nasabah Bank Syariah Mandiri Kantor Cabang Boulevard di Surabaya. JESTT Vol. 1 No. 8.

Wulandari, Mega Fitria. 2017. Determinasi IER (Internar, Eksternar dan Religiusitas) dalam Intensiterhadap Perilaku Nasabah untuk Cash Waqf di Perbankan Syariah. Fakultas Ekonomi dan Bisnis UIN Syarif Hidayatullah. 